\title{
Pax5 induces $V$-to- $D J$ rearrangements and locus contraction of the immunoglobulin heavy-chain gene
}

\author{
Martin Fuxa, ${ }^{1,3}$ Jane Skok, ${ }^{2,3}$ Abdallah Souabni, ${ }^{1}$ Giorgia Salvagiotto, ${ }^{1}$ Esther Roldan, ${ }^{2}$ and \\ Meinrad Busslinger ${ }^{1,4}$ \\ ${ }^{1}$ Research Institute of Molecular Pathology, Vienna Biocenter, A-1030 Vienna, Austria; ${ }^{2}$ Department of Immunology and \\ Molecular Pathology, University College London, London W1T 4JF, UK
}

\begin{abstract}
The subnuclear location and chromatin state of the immunoglobulin heavy-chain $(\mathrm{IgH})$ locus have been implicated in the control of $V(D) J$ recombination. $V_{H}$-to- $D J_{H}$ rearrangement of distal, but not proximal $V_{H}$ genes, furthermore, depends on the B-lineage commitment factor Pax5 (BSAP). Here we demonstrate that ectopic Pax 5 expression from the Ikaros promoter induces proximal rather than distal $V_{H^{-}}-D J_{H}$ rearrangements in $\mathrm{Ik}^{\mathrm{Pax} 5 /+}$ thymocytes, thus recapitulating the loss-of-function phenotype of $\mathrm{Pax}^{-/-}$pro-B cells. The phenotypic similarities of both cell types include (1) chromatin accessibility of distal $V_{H}$ genes in the absence of $V_{H}-D J_{H}$ rearrangements, (2) expression of the B-cell-specific regulator EBF, (3) central location of IgH alleles within the nucleus, and (4) physical separation of distal $V_{H}$ genes from proximal segments in an extended $\operatorname{IgH}$ locus. Reconstitution of $\operatorname{Pax} 5$ expression in $\mathrm{Pax}^{-/-}$pro-B cells induced large-scale contraction and distal $V_{H^{-}}-D J_{H}$ rearrangements of the $I g H$ locus. Hence, $V_{H^{-}}-D J_{H}$ recombination is regulated in two steps during early B-lymphopoiesis. The $\mathrm{IgH}$ locus is first repositioned from its default location at the nuclear periphery toward the center of the nucleus, which facilitates proximal $V_{H^{-}}-D J_{H}$ recombination. Pax5 subsequently activates locus contraction and distal $V_{H}-D J_{H}$ rearrangements in collaboration with an unknown factor that is present in pro-B cells, but absent in thymocytes.
\end{abstract}

[Keywords: Pax5/BSAP; $V_{H}-D I_{H}$ recombination; immunoglobulin heavy-chain; locus contraction; subnuclear location; $\mathrm{T}$ cells]

Supplemental material is available at http://www.genesdev.org.

Received November 10, 2003; revised version accepted January 12, 2004.

$V(D) J$ recombination is of fundamental importance for the generation of diverse antigen receptor repertoires, as this process assembles the variable regions of immunoglobulin $(I g)$ and T-cell receptor $(T C R)$ genes from discontinuous variable $(V)$, diversity $(D)$, and joining $(J)$ gene segments during B- and T-cell development (Tonegawa 1983; Hesslein and Schatz 2001). All of these gene segments are flanked by conserved recombination signal sequences (RSSs) that constitute recognition sites for the $\mathrm{V}(\mathrm{D}) \mathrm{J}$ recombinase proteins RAG1 and RAG2 (Hesslein and Schatz 2001; Bassing et al. 2002). Upon binding and synapsis of two compatible RSS sites, the RAG1/2 complex introduces double-strand DNA breaks between the RSSs and flanking gene segments. Subsequently, the RAG proteins and repair factors of the nonhomologous end-joining machinery complete the recombination re-

\footnotetext{
${ }^{3}$ These authors contributed equally to this work.

${ }^{4}$ Corresponding author.

E-MAIL busslinger@imp.univie.ac.at; FAX 43-1-798-93-70.

Article and publication are at http://www.genesdev.org/cgi/doi/10.1101/ gad.291504.
}

action by processing and religating the DNA ends (Hesslein and Schatz 2001; Bassing et al. 2002).

$V(D) J$ recombination takes place only in lymphocytes, where it is tightly controlled in a lineage- and stagespecific manner. Within the B-lymphoid lineage, the immunoglobulin heavy-chain $(\operatorname{IgH})$ locus is rearranged in pro-B cells prior to recombination of the $I g \kappa$ and $I g \lambda$ light-chain genes in pre-B cells, whereas the TCR $\beta$ and $T C R \alpha$ genes are rearranged in pro- $\mathrm{T}$ and pre- $\mathrm{T}$ cells, respectively (Hesslein and Schatz 2001; Bassing et al. 2002). As the RAG1 and RAG2 genes are expressed in all lymphoid progenitors (Igarashi et al. 2002) and immature $\mathrm{T}$ cells and $\mathrm{B}$ cells, $V(D) J$ recombination is primarily regulated by limiting the accessibility of RSS sites within chromatin (Yancopoulos and Alt 1985; StanhopeBaker et al. 1996; Krangel 2003). As a consequence, only the sites of particular gene segments are available for RAG1/2-mediated synapsis and DNA cleavage in different cell types and developmental stages.

$V(D) J$ recombination of the $I g H$ gene occurs in a defined temporal order with $D_{H}-J_{H}$ rearrangements preceding $V_{H^{-}}-D I_{H}$ recombination. The earliest lymphocyte 
progenitor (ELP; Igarashi et al. 2002) and later common lymphoid progenitor (CLP; Allman et al. 2003) already initiate $D_{H}-J_{H}$ rearrangements, which are completed during development to the early pro-B-cell stage (fraction B; Li et al. 1993). As the ELP and CLP also give rise to T, NK, and dendritic cells (Kondo et al. 1997; Traver et al. 2000; Igarashi et al. 2002), it may not be surprising that these cell types carry $D_{H}-J_{H}$-rearranged $I g H$ alleles at low frequency (Kurosawa et al. 1981; Born et al. 1988; Corcoran et al. 2003). Importantly, $V_{H}-D J_{H}$ rearrangements could never be observed in thymocytes and dendritic cells (Kurosawa et al. 1981; Corcoran et al. 2003), as the second $I g H$ rearrangement step takes place only in committed pro-B cells (fractions B and C; Li et al. 1993). Successful $V_{H}-D J_{H}$ recombination leads to expression of the Ig $\mu$ protein as part of the pre-B-cell receptor (preBCR), which acts as an important checkpoint to control the transition from the pro-B- to the pre-B-cell stage (Burrows et al. 2002).

The $I g H$ locus with its $150-200 V_{H}$ genes spans a large chromosomal region of $\sim 3 \mathrm{Mb}$ pairs (Chevillard et al. 2002), which is likely to be an impediment for efficient synapse formation and $V(D) J$ recombination of distantly separated $\operatorname{IgH}$ gene segments. A recent fluorescent in situ hybridization (FISH) analysis revealed that $V(D) J$ recombination correlates with changes in the subnuclear location and chromatin state of the IgH locus (Kosak et al. 2002). Both $\operatorname{IgH}$ alleles are present in an extended chromatin configuration at the nuclear periphery of nonB-lymphoid cells, whereas they are relocated to central positions of the nucleus and undergo large-scale contraction in committed pro-B cells (Kosak et al. 2002). Subnuclear compartmentalization was thus proposed as a novel mechanism for regulating $\operatorname{Ig} H$ transcription and recombination during B-cell development (Kosak et al. 2002), particularly because the nuclear periphery in higher eukaryotes may function as a repressive compartment for transcriptional silencing (Baxter et al. 2002) in analogy to yeast (Hediger and Gasser 2002).

Differentiation of the CLP to committed pro-B cells critically depends on the three transcription factors E2A, EBF, and Pax5 (BSAP; Schebesta et al. 2002a). All three factors are also essential for $V(D) J$ recombination of the $\mathrm{IgH}$ gene during early B-cell development. The absence of E2A or EBF arrests B-cell development at the stage of $\mathrm{B} 220^{+} \mathrm{CD}_{4} 3^{+}$progenitor cells (fraction A) that contain the $\mathrm{IgH}$ locus still in germ-line configuration (Bain et al. 1994; Lin and Grosschedl 1995). Both transcription factors appear to control the initial $D_{H}-J_{H}$ rearrangement step by activating the expression of RAG1 and RAG2 (Bain et al. 1994; Lin and Grosschedl 1995; O'Riordan and Grosschedl 1999) and by promoting the accessibility of the $D_{H}-J_{H}$ region to the $\mathrm{V}(\mathrm{D}) \mathrm{J}$ recombinase (Romanow et al. 2000). In the absence of Pax5, B-lymphopoiesis proceeds in the bone marrow to early pro-B cells (fraction B; Urbánek et al. 1994; Nutt et al. 1997), which still retain a broad lympho-myeloid developmental potential characteristic of uncommitted progenitors (Nutt et al. 1999; Rolink et al. 1999). Restoration of Pax5 expression in $\mathrm{Pax}^{-/-}$pro-B cells suppresses this multilineage poten- tial and rescues development to mature B cells, thus identifying Pax5 as the critical B-lineage commitment factor that restricts the developmental options of lymphoid progenitors to the B-cell pathway (Nutt et al. 1999). In addition, Pax5 controls the second, B-cell-restricted step of $V_{H}-D J_{H}$ recombination, as rearrangements of the distal $\left(5^{\prime}\right) V_{H} J 558$ genes are $\sim 50$-fold reduced in $\mathrm{Pax}^{-/-}$pro-B cells, although $D_{H^{-}} J_{H}$ recombination occurs at normal frequency (Nutt et al. 1997). Despite this defect, the distal $V_{H}$ genes are present in accessible chromatin, as indicated by their germ-line transcription and histone $\mathrm{H} 3$ acetylation in $\mathrm{Pax}^{-/-}$pro-B cells (Hesslein et al. 2003). Interestingly, the $V_{H}-D J_{H}$ recombination efficiency of $\mathrm{Pax}^{-/-}$pro-B cells progressively increases with decreasing distance of the $V_{H}$ gene to the proximal $D_{H}-J_{H}$ region (Hesslein et al. 2003). Hence, Pax5 is essential for the rearrangement of distal but not proximal $V_{H}$ genes.

Pax5 is expressed within the hematopoietic system exclusively from the pro-B- to the mature B-cell stage, consistent with its role as B-lineage commitment factor (Adams et al. 1992). We have recently complemented our Pax5 loss-of-function analyses with a gain-of-function approach by expressing a human Pax5 minigene under the control of the endogenous Ikaros (Ik) locus in all blood cell types (Souabni et al. 2002). Pan-hematopoietic expression of the $I k^{\text {Pax } 5}$ allele efficiently promotes B-cell development at the expense of T-lymphopoiesis. Whereas ectopic Pax5 expression completely blocks Tcell development in chimeric mice reconstituted with wild-type and $\mathrm{Ik}^{\mathrm{Pax} 5 /+}$ bone marrow, thymocyte differentiation is reduced and abnormal under noncompetitive conditions in $\mathrm{Ik}^{\mathrm{Pax} 5 /+}$ mice (Souabni et al. 2002). At the molecular level, Pax5 down-regulates transcription of the T-cell specification gene Notch1 and activates expression of the B-lymphoid gene CD19 in thymocytes (Souabni et al. 2002).

By analyzing the rearrangement status of the $\mathrm{IgH}$ locus in $I k^{P a x 5 /+}$ thymocytes, we now demonstrate that ectopic Pax5 expression is sufficient to increase $D_{H}-J_{H}$ recombination and to initiate $V_{H}-D J_{H}$ rearrangements in immature cells of the T-lymphoid lineage. Unexpectedly, the $V_{H}-D I_{H}$ recombination phenotype of Pax5-expressing thymocytes resembles that of Pax5-deficient pro-B cells. The distal $V_{H} J 558$ and $V_{H} 3609$ genes are rearranged with very low efficiency in contrast to the proximal $V_{H} Q 52$ and $V_{H} 7183$ genes, although germ-line transcripts of the distal $V_{H} J 558$ genes could be readily detected in $\mathrm{Ik}^{\mathrm{Pax} 5 /+}$ pro- $\mathrm{T}$ cells as in $\mathrm{Pax}^{-/-}$pro-B cells. Importantly, the expression of the B-cell-specific transcription factor EBF was induced to the same level in $\mathrm{Ik}^{\text {Pax } 5 /+}$ pro-T cells as in $\mathrm{Pax}^{-/-}$pro-B cells. FISH analysis of three-dimensionally preserved nuclei further extended the phenotypic similarity between $I k^{\text {Pax } 5 /+}$ pro- $\mathrm{T}$ and $\mathrm{Pax}^{-/-}$pro-B cells. The $I g H$ alleles were centrally located in the nuclei of both cell types and were present in an extended chromatin state that physically separates the distal from the proximal $V_{H}$ genes. In contrast, the $\operatorname{Ig} H$ loci were localized at the nuclear periphery in wildtype pro-T cells. In Pax5-expressing pro-B cells, the $\operatorname{IgH}$ 
loci were found in central nuclear positions and underwent large-scale contraction, as published (Kosak et al. 2002). Moreover, Pax5 induced IgH locus contraction and distal $V_{H}-D J_{H}$ rearrangements in retrovirally reconstituted $\mathrm{Pax}^{-/-}$pro-B cells. Based on these data, we propose a two-step model for the transcriptional activation of $V_{H}-D J_{H}$ recombination in early B-cell development. The IgH locus is first relocated, possibly under the control of EBF, from the periphery to the center of the nucleus, thus facilitating $V_{H}-D J_{H}$ recombination within the proximal domain of the $I g H$ locus. Subsequently, Pax5 activates large-scale contraction and distal $V_{H}-D J_{H}$ rearrangements of the $\mathrm{IgH}$ locus in collaboration with an unknown factor that is present in pro-B cells, but absent in thymocytes.

\section{Results}

Pax5 induces $\mathrm{D}_{\mathrm{H}}-\mathrm{J}_{\mathrm{H}}$ and $\mathrm{V}_{\mathrm{H}}-\mathrm{DJ}_{\mathrm{H}}$ rearrangements at the $\mathrm{IgH}$ locus in $\mathrm{Ik}^{\mathrm{Pax} 5 /+}$ thymocytes

To investigate whether ectopic Pax5 expression is able to induce $I g H$ rearrangements in $\mathrm{T}$ cells, we isolated $\mathrm{CD}^{-}{ }^{-} \mathrm{CD} 8^{-}$double-negative $(\mathrm{DN})$ pro- $\mathrm{T}$ cells and $\mathrm{CD}^{+}$ $\mathrm{CD}^{+}$double-positive (DP) pre-T cells from the thymus of 2 -week-old $\mathrm{Ik}^{\mathrm{Pax} 5 /+}$ and control $\mathrm{Ik}^{\text {neo/+ }}$ mice (Souabni et al. 2002) by FACS sorting after depletion of $\mathrm{B} 220^{+}$ B-lymphocytes. As positive control, we sorted c-Kit ${ }^{+}$ $\mathrm{B} 220^{+}$pro-B cells from the bone marrow of wild-type and $\mathrm{Pax}^{-/-}$mice (Urbánek et al. 1994). DNA was isolated from the different cell types and normalized by PCR amplification of a DNA fragment from the $\mathrm{IgH} C \mu$ region prior to quantitative PCR analysis of $D_{H}-J_{H}$ and $V_{H}-D J_{H}$ rearrangements (Fig. $1 \mathrm{~B}$ ). No $V_{H}-D J_{H}$ rearrangements and only a low level of $D_{H^{-}} J_{H}$ rearrangements were detected in control $\mathrm{Ik}^{\text {neo/+ }}$ thymocytes (Fig. 1B), as previously described for wild-type $\mathrm{T}$ cells (Kurosawa et al. 1981; Born et al. 1988). The frequency of $D_{H}-J_{H}$ recombination was increased fivefold in $I k^{\text {Pax } 5 /+}$ thymocytes, reaching half the level observed in wild-type and $\mathrm{Pax}^{-{ }^{-/}}$ pro-B cells (Fig. 1B,C). Hence, ectopic Pax5 expression promotes further $D_{H}-J_{H}$ recombination in thymocytes. More importantly, Ik Pax5/+ thymocytes carried $V_{H}-D J_{H}$ rearrangements (Fig. 1B), which are normally restricted to the B-lymphoid lineage (Kurosawa et al. 1981). The proximal $V_{H} 7183$ and $V_{H} Q 52$ genes (Fig. 1A) were rearranged in $I k^{\text {Pax } 5 /+}$ pre-T cells as efficiently as in wildtype pro-B cells, whereas a slightly lower level of proximal $V_{H} 7183$ and $V_{H} Q 52$ gene rearrangements was detected in $\mathrm{Ik}^{\text {Pax } 5 /+}$ pro-T cells (Fig. 1B). Unexpectedly however, the recombination frequency of the more distal $V_{H}$ Gam3.8, $V_{H} 3609$, and $V_{H} J 558$ genes (Fig. 1A) was reduced 30- to 100 -fold in $I k^{\text {Pax } 5 /+}$ pro- $\mathrm{T}$ and pre-T cells in contrast to wild-type pro-B cells (Fig. 1B). A similar position-dependent decrease of $V_{H}$ gene recombination was observed in $\mathrm{Pax}^{-/-}$pro-B cells (Fig. 1B), in agreement with recently published data (Hesslein et al. 2003). Hence, ectopic expression of $\operatorname{Pax} 5$ leads to the same $V_{H^{-}}$ $D J_{H}$ recombination phenotype in thymocytes as does the loss of Pax5 in pro-B cells. In summary, these data indi-
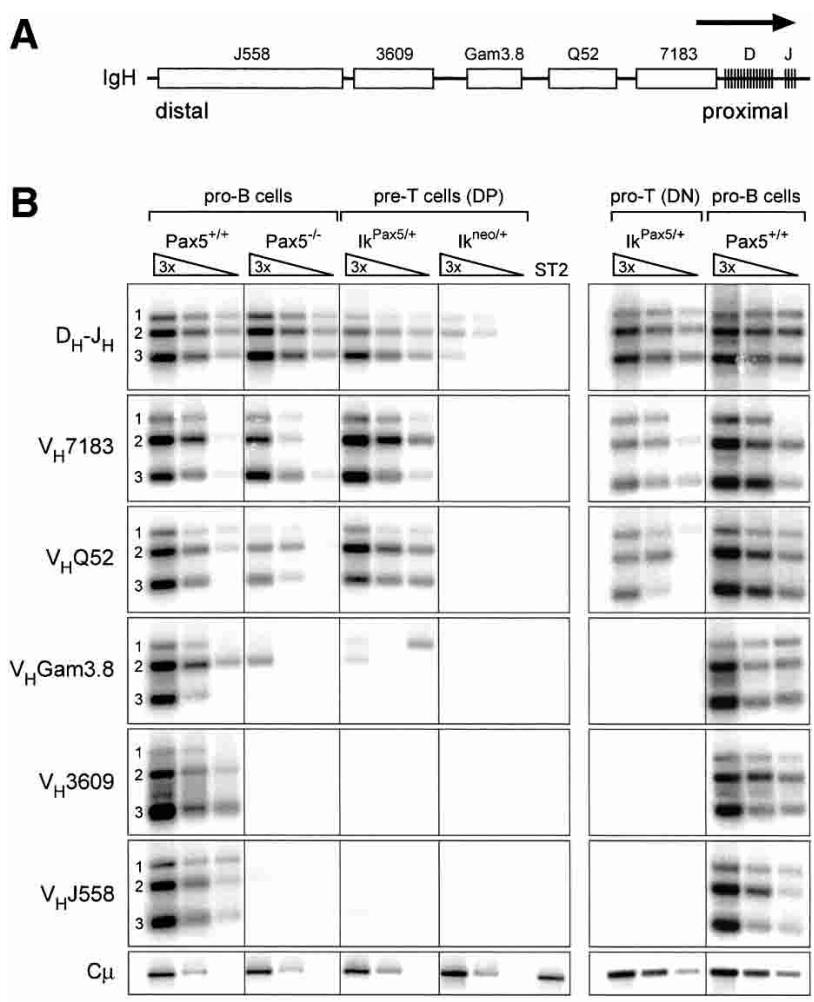

C

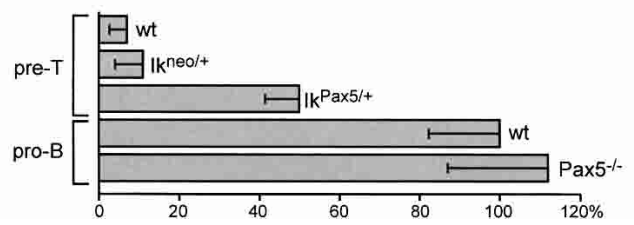

Figure 1. Pax5 induces $D_{H}-J_{H}$ and $V_{H}-D J_{H}$ rearrangements of the $I g H$ locus in thymocytes. (A) Schematic diagram of the $V_{H}$ gene cluster of the $I g H$ locus. Only the $V_{H}$ gene families analyzed are shown together with their transcriptional direction (arrow) and distal or proximal position within the $V_{H}$ gene cluster. (B) PCR detection of $D_{H}-I_{H}$ and different $V_{H}-D I_{H}$ rearrangements in $I k^{\text {Pax } 5 /+}$ and $I k^{\text {neo/+ }}$ thymocytes (pro-T [DN] and pre-T [DP] cells) as well as in bone marrow $\mathrm{Pax}^{+/+}$and $\mathrm{Pax}^{-/-}$pro-B cells, which were directly sorted from 2 -week-old mice. Threefold serial DNA dilutions were analyzed by PCR. Input DNA was normalized by amplification of a PCR fragment from the IgH C $\mu$ regions, and DNA of the stromal ST2 cells was used as negative control. Numbers to the left indicate rearrangements to the $J_{H} 1, J_{H} 2$, and $I_{H} 3$ segments. $(C)$ Quantitation of $D_{H}-J_{H}$ recombination in sorted pro-B and pre-T cells. $D_{H^{-}} I_{H}$ rearrangements were analyzed by PCR in three independent preparations of sorted cells of the indicated genotypes. The average recombination frequency with its standard deviation is shown as relative percentage of the rearrangements detected in wild-type (wt) pro-B cells.

cate that $\operatorname{Pax} 5$ is sufficient to induce $V(D) J$ recombination within the proximal $\operatorname{IgH}$ domain in thymocytes. However, efficient rearrangement of the distal $V_{H}$ genes appears to require the cooperation of Pax5 with an unidentified second factor that is absent in Pax5-overexpressing $\mathrm{T}$ cells. 
Surface Ig $\mu$ expression in the absence of $\operatorname{Ig}_{\kappa}$ rearrangements in $\mathrm{Ik}^{\mathrm{Pax} 5 /+}$ thymocytes

Sequence analysis of the $V_{H} D I_{H} 2$ PCR fragments revealed that $V(D) J$ recombination in $I k^{P a x 5 /+}$ pre-T cells involved different members of the $V_{H} 7183$ and $V_{H} Q 52$ gene families, although with a strong bias for more proximally located genes within each family (data not shown). Moreover, $13 \%$ of the sequenced PCR fragments contained a functional in-frame $V_{H}-D J_{H}$ rearrangement (data not shown). This finding was confirmed by flow cytometric analysis demonstrating that functionally rearranged Ig $\mu$ chains were expressed not only in the cytoplasm, but also on the cell surface of Thy $1.2^{+} I k^{\text {Pax } 5 /+}$ thymocytes at the expected frequency (Fig. 2A). However, no $V_{\kappa}-I_{\kappa}$ rearrangements could be detected in $I k^{\text {Pax } 5 /+}$ pre-T cells, demonstrating that Pax 5 is unable to induce rearrangements at the Igк light-chain locus (Fig. $2 B)$. As a consequence, the productively rearranged Ig $\mu$ protein is likely to be expressed as part of the pre-BCR on the cell surface of $I k^{\text {Pax5/++ }}$ thymocytes, which is consistent with expression data shown below. Most $I k^{\text {Pax 5/+ }}$ thymocytes expressed TCR $\beta$ on the cell surface (Fig. 2A), in agreement with the observation that $D_{\beta} 2-J_{\beta} 2$ and $V_{\beta} 5.1-D J_{\beta} 2$ rearrangements were present at similar frequency in $I k^{\text {Pax } 5 /+}$ and control $I k^{\text {neo/+ }}$ pre-T cells (Fig. 2B). These data further demonstrate that the $I k^{\text {Pax } 5 /+}$ thymocytes are of T-lymphoid origin despite ectopic expression of the B-lineage commitment factor Pax5 (Souabni et al. 2002).

Conditional Pax5 activation induces $\mathrm{V}_{\mathrm{H}}-\mathrm{DJ} \mathrm{J}_{\mathrm{H}}$ rearrangements within the T-lymphoid lineage

The expression of RAG1 and RAG2 is initiated in the earliest lymphocyte progenitor (ELP), resulting in subsequent $D_{H}-J_{H}$ recombination (Igarashi et al. 2002). Hence, the $V(D) /$ rearrangement machinery is already active in lymphoid progenitors of the bone marrow prior to B- and T-lineage commitment. On the other hand, expression of the $I k^{\text {Pax } 5}$ allele is initiated in the hematopoietic stem cell and is maintained in the progenitors and differentiating cells of all major hematopoietic lineages (Souabni et al. 2002). It is therefore conceivable that the Pax5expressing lymphoid progenitors of $\mathrm{Ik}^{\mathrm{Pax} 5 /+}$ mice may undergo $V_{H}-D I_{H}$ rearrangements before migration to the thymus and initiation of T-cell development. Alternatively, the $V_{H}-D I_{H}$ rearrangements present in $I k^{\text {Pax5/+ }}$ thymocytes may originate within the T-lymphoid lineage. To distinguish between these two possibilities, we took advantage of the conditional $I k^{n e o}$ allele, which contains a floxed neomycin stop cassette upstream of the Pax5 minigene in the Ikaros locus (Souabni et al. 2002). Pax5 expression from this allele is only activated upon Cre recombinase-mediated deletion of the neomycin gene (Souabni et al. 2002). To this end, we crossed the $I^{n e o /+}$ mouse with a transgenic mouse, which expressed the Cre recombinase under the control of the proximal lck promoter (lck-cre) during pro-T-cell development (Lee et al. 2001; Wolfer et al. 2002). The lck-cre transgene
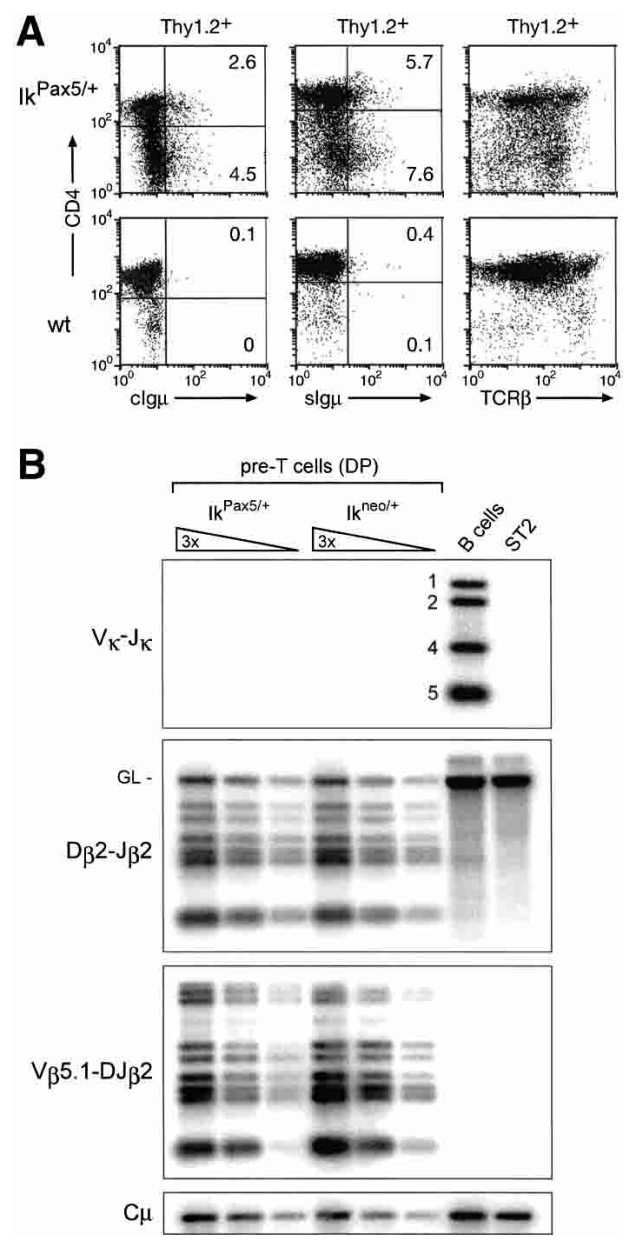

Figure 2. Surface Ig $\mu$ expression in the absence of $I g_{\kappa}$ rearrangements in $I k^{\text {Pax } 5 /+}$ thymocytes. (A) Flow cytometric analysis. Cytoplasmic (c) and cell surface (s) expression of functionally rearranged Ig $\mu$ protein and cell surface TCR $\beta$ expression were analyzed in wild-type (wt) and $I k^{\mathrm{Pax} 5 /+}$ thymocytes (gated as Thy $1.2^{+}$cells). The percentage of Ig $\mu^{+}$cells is indicated. $(B)$ Normal TCR $\beta$ recombination and absence of $V_{K}-J_{K}$ rearrangements in $I k^{\text {Pax 5/+ }}$ thymocytes. The same sorted $\mathrm{Ik}^{\text {Pax5/+ }}$ and $I k^{n e o /+}$ pre-T cells, which were used for the experiment shown in Figure 1, were analyzed by PCR for $V_{K}-I_{K}$ rearrangements at the $I g_{\kappa}$ locus and for $D_{\beta} 2-I_{\beta} 2$ and $V_{\beta} 5.1-D I_{\beta} 2$ rearrangements at the TCR $\beta$ locus. Splenic B220 B cells and stromal ST2 cells served as positive and negative controls, respectively. The numbers next to the B-cell lane indicate rearrangements to the $J_{K} 1$, $J_{K} 2, J_{K} 4$, and $J_{K} 5$ segments. GL denotes the position of the germline PCR product.

was shown to initiate Cre-mediated inactivation of a floxed Notch1 allele in CD44 ${ }^{+} \mathrm{CD} 25^{+}(\mathrm{DN} 2)$ pro-T cells and to complete gene deletion in $\mathrm{CD}_{4} 4^{-} \mathrm{CD} 25^{+}(\mathrm{DN} 3)$ pro-T cells (Wolfer et al. 2002). However, the same lckcre transgene deleted the floxed neomycin gene of the $I k^{\text {neo }}$ allele with lower efficiency, as the activated $I k^{\text {Pax } 5}$ allele was detected in only $\sim 60 \%$ of pre-T cells (Fig. 3 ). Nevertheless, these thymocytes of $I k^{\text {neo/+ }} 1$ ck-cre mice were characterized by an increase in $D_{H}-J_{H}$ rearrangements and the presence of $V_{H}-D J_{H}$-rearranged $I g H$ alleles (Fig. 3). The $V_{H}-D I_{H}$ rearrangement frequency was high- 


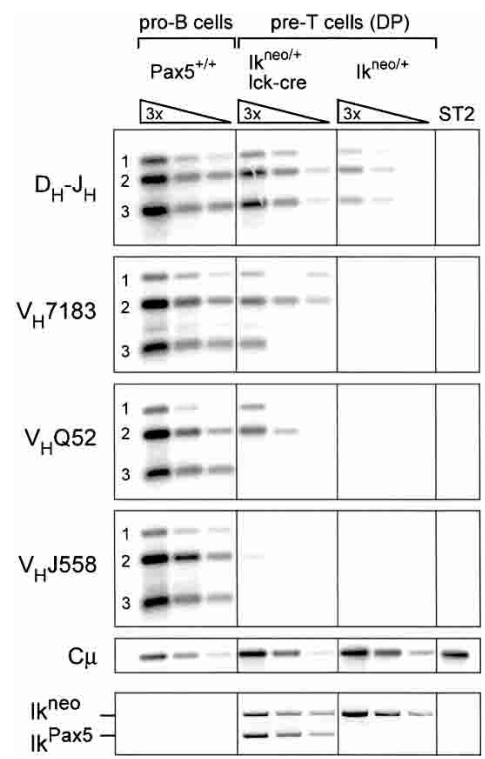

Figure 3. $V_{H}-D I_{H}$ rearrangements upon conditional Pax5 activation in thymocytes. Pre-T cells were isolated by FACS sorting as DP thymocytes from $I k^{\text {neo/+ }}$ mice carrying the lck-cre transgene followed by PCR quantification of $D_{H^{-}} I_{H}$ and $V_{H^{-}}-D I_{H}$ rearrangements as described in Figure $1 \mathrm{~B}$. $I k^{\text {neo/+ }}$ pre-T cells and stromal ST2 cells served as negative controls and $\mathrm{Pax}^{+/+}$pro-B cells as positive control for the detection of $V_{H}-D T_{H}$ rearrangements. Cre-mediated conversion of the $I k^{\text {neo }}$ to the $I k^{P a x 5}$ allele was determined by PCR (bottom row).

est for the proximal $V_{H} 7183$ genes and lowest for the distal $V_{H} 558$ gene family (Fig. 3 ), thus recapitulating the $V(D) J$ recombination phenotype of $I k^{P a x 5 /+}$ thymocytes (Fig. 1B). The rearrangement frequency was, however, lower in $I k^{n e o /+} 1 c k$-cre pre-T cells, possibly because of the inefficient activation of the $I k^{\text {neo }}$ allele during T-cell development. Together these data unequivocally demonstrate that Pax5 is able to induce $V_{H}-D I_{H}$ rearrangements within the T-lymphoid lineage.

Pax5 activates germ-line $\mathrm{V}_{\mathrm{H}}$ transcription and multiple B-lymphoid genes in pro-T cells

To study the extent of B-cell-specific gene activation by Pax5 in thymocytes, we purified pro-T cells from $I k^{P a x 5 /+}$ mice by depleting Lin $^{+}$cells (including $\mathrm{B}^{2} 2 \mathrm{O}^{+} \mathrm{B}$ cells), followed by sorting for Thy $1.2^{+} \mathrm{Lin}^{-} \mathrm{DN}$ thymocytes. Flow cytometric reanalysis demonstrated that the sorted Thy $1.2^{+}$Lin $^{-}$pro-T cells were purified to homogeneity (Fig. 4A). Moreover, RT-PCR analysis failed to detect rearranged $I g \kappa$ and $I g \lambda 1$ mRNAs in these sorted cells (Fig. 4B). We conclude, therefore, that the sorted $\mathrm{Ik}^{\text {Pax } 5 /+}$ pro- $\mathrm{T}$ cells were free of contaminating B cells. In addition, we sorted wild-type pro- $\mathrm{T}$ and pro-B cells as well as $\mathrm{Pax}^{-/-}$pro-B cells. cDNA was prepared from all four cell types and normalized for equal expression of the control HPRT gene prior to semiquantitative RT-PCR analysis of B-cell-specific transcripts (Fig. 4C).

The accessibility of a particular $V_{H}$ gene in active chromatin can be monitored by expression of its germline transcript (GLT), whereas the abundance of spliced $I g \mu\left(V_{H^{-}}-D J C \mu\right)$ mRNA is a direct measure of the $V_{H^{-}}-D I_{H}$ recombination frequency in progenitor cells (Yancopoulos and Alt 1985). The germ-line transcripts of the proximal $V_{H} 7183$ gene family were expressed at a fivefold
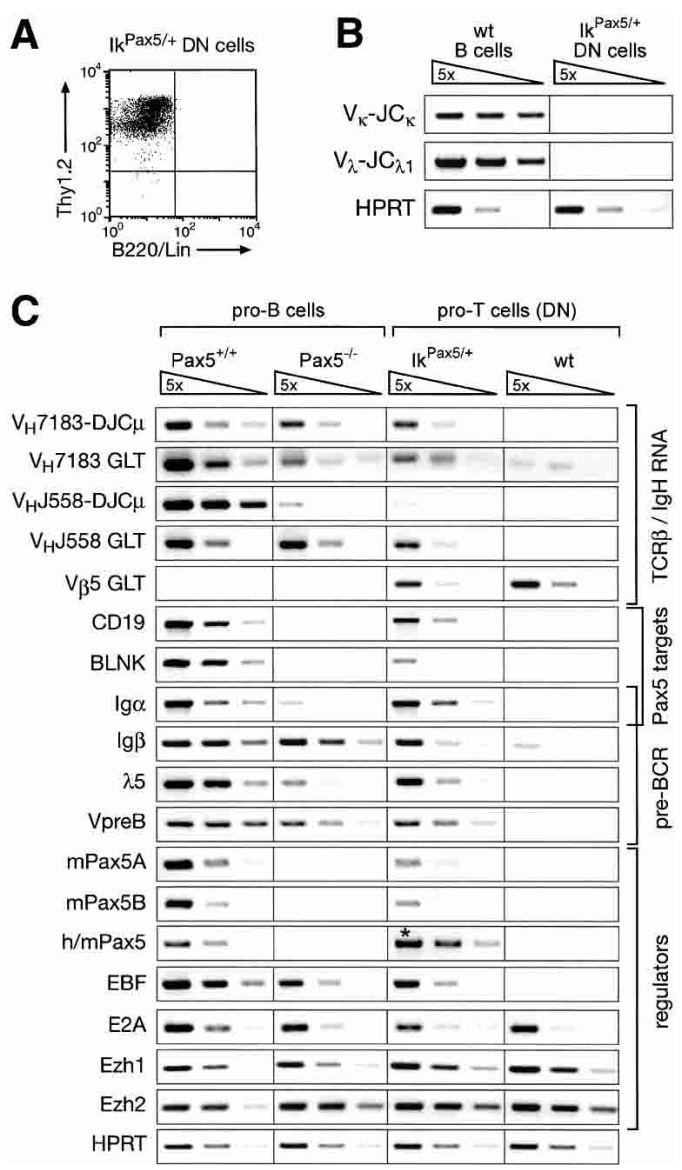

Figure 4. Activation of germ-line $V_{H}$ transcription and B-cellspecific gene expression in $I k^{\text {Pax 5/+ }}$ pro-T cells. (A) Flow cytometric reanalysis of sorted $I k^{P a x 5 /+} \mathrm{DN}$ thymocytes. DN pro-T cells of 2-week-old mice were sorted as Thy $1.2^{+} \mathrm{Lin}^{-}$cells after depletion of $\mathrm{Lin}^{+}$cells, which were stained with antibodies recognizing B220, CD4, CD8, DX5, CD11c, Mac-1, Gr-1, and Ter119. (B) Absence of B cells in the sorted $I k^{\text {Pax } 5 /+}$ pro-T cell population. Rearranged $\operatorname{Ig} \kappa\left(V_{K}-J C_{K}\right)$ and $\operatorname{Ig} \lambda 1\left(V_{\lambda}-J C_{\lambda 1}\right)$ mRNAs could not be detected by RT-PCR in purified $I k^{\text {Pax } 5 /+^{+}}$pro-T cells in contrast to $\operatorname{IgM}^{+} \operatorname{IgD}^{+} \mathrm{B}$ cells isolated from wild-type (wt) spleen. The hypoxanthine phosphoribosyltransferase (HPRT) gene was equally expressed in both cell types. $(C)$ B-cell-specific gene expression in $\mathrm{Ik}^{\mathrm{Pax} 5 /+}$ pro-T cells. Transcripts of the indicated genes were analyzed by semiquantitative RT-PCR of fivefold serial dilutions of cDNA that was prepared from ex vivo sorted pro-B cells and pro-T cells of the indicated genotypes. The cDNA input was normalized according to the expression of the control HPRT gene. $V_{H} J 558-D / C \mu$ and $V_{H} 7183-D / C \mu$ refer to rearranged $I g \mu$ mRNAs and GLT to the corresponding germline transcripts. Transgenic human (h) and endogenous mouse (m) Pax5 transcripts were amplified with conserved primers, giving rise to the same PCR fragment (denoted by an asterisk) for both transcripts. 
lower level in $\mathrm{Pax}^{-/-}$pro-B cells and $\mathrm{Ik}^{\mathrm{Pax} 5 /+}$ pro-T cells compared with wild-type pro-B cells. The rearranged mRNAs of the $V_{H} 7183$ genes were, however, present at similar abundance in all three cell types (Fig. 4C), consistent with efficient $V_{H} 7183-D J_{H}$ recombination in these cells (Fig. 1B; Hesslein et al. 2003). In contrast, the rearranged mRNA of the distal $V_{H} J 558$ gene family was reduced $\sim 100$-fold in $\mathrm{Ik}^{\mathrm{Pax} 5 /+}$ pro-T cells and $\mathrm{Pax}^{-/-}$ pro-B cells (Fig. 4C), which undergo $V_{H} J 558-D I_{H}$ rearrangements with a similarly low efficiency compared with wild-type pro-B cells (Fig. 1B; Nutt et al. 1997). Germ-line $V_{H} J 558$ transcripts were, however, present at a similar abundance in $I k^{\text {Pax5/+ }}$ pro- $\mathrm{T}$ cells relative to wild-type and $\mathrm{Pax}^{-1-}$ pro-B cells (Fig. 4C). Germ-line transcripts of the TCR $V_{\beta} 5$ gene could not be detected in pro-B cells, but were expressed in $I k^{\operatorname{Pax} 5 /+}$ pro- $\mathrm{T}$ cells, further confirming the T-lymphoid origin of these cells (Fig. 4C). These data indicate, therefore, that ectopic expression of Pax5 establishes an accessible chromatin state at both the proximal and distal $V_{H}$ genes in $I k^{\text {Pax } 5 /+}$ pro- $\mathrm{T}$ cells, although only the proximal $V_{H}$ genes undergo efficient $V_{H}-D I_{H}$ recombination.

Ectopic Pax5 expression activated the Pax5 target genes CD19 (Nutt et al. 1998), BLNK (Schebesta et al. 2002b), and Ig $\alpha$ (mb-1; Nutt et al. 1998) in Ik ${ }^{\text {Pax5/+ }}$ pro-T cells (Fig. 4C). More surprisingly, these pro-T cells also expressed the genes $\operatorname{Ig} \beta$ (B29), $\lambda 5$, and VpreB (Fig. 4C), which are known to be cooperatively regulated by the transcription factors EBF and E2A (Sigvardsson et al. 1997, 2002; O'Riordan and Grosschedl 1999). Consistent with this finding, Pax 5 induced expression of the B-cellspecific EBF gene in $I k^{\text {Pax } 5 /+}$ pro-T cells to a level that is normally seen in wild-type and $\mathrm{Pax}^{-/-}$pro-B cells. In contrast, the expression of E2A was similar and independent of Pax5 in pro-T cells as in pro-B cells (Fig. 4C). None of the B-cell-specific transcripts analyzed could be detected in wild-type pro-T cells except for low-level expression of the Ig $\beta$ gene (Wang et al. 1998). Moreover, the efficient expression of all pre-BCR components $(\lambda 5$, VpreB, $\operatorname{Ig} \alpha$, and $\operatorname{Ig} \beta$ ) strongly suggests that the rearranged Ig $\mu$ protein is transported as part of the pre-BCR to the cell surface of $I k^{\text {Pax5/+ }}$ thymocytes (Fig. 2A).

The Pax5 gene gives rise to two distinct mRNAs by alternative promoter usage and splicing of the different $5^{\prime}$-exons onto common coding sequences (Busslinger et al. 1996). The presence of the mouse Pax $5 A$ and $P a x 5 B$ transcripts in $I k^{P a x 5 /+}$ pro- $T$ cells demonstrated that the ectopically expressed human Pax 5 protein is able to induce transcription of the endogenous Pax5 gene in thymocytes (Fig. 4C). This Pax5 activation is likely to be an indirect effect of EBF expression, which is known to regulate the Pax5 gene in pro-B cells $\left(\mathrm{O}^{\prime}\right.$ Riordan and Grosschedl 1999). PCR conditions, which detect human and mouse Pax 5 mRNAs with equal efficiency, revealed that the human Pax5 minigene of the $I k^{\text {Pax5 }}$ allele is expressed at a fivefold higher level in pro-T cells compared with the endogenous Pax5 gene in wild-type pro-B cells (Fig. 4C). In conclusion, moderate overexpression of Pax5 activates its own gene as well as many other B-cellspecific genes in $I k^{\text {Pax5/+ }}$ pro-T cells.
Relocation of the IgH locus from the nuclear periphery to central positions in $\mathrm{Ik}^{\mathrm{Pax} 5 /+}$ thymocytes

A recently published FISH analysis indicated that the subnuclear location and chromatin state of the $\mathrm{IgH}$ locus may regulate $V(D) /$ recombination in non-B versus pro-B cells (Kosak et al. 2002). In particular, the 3-Mb-long IgH locus with its 150-200 $V_{H}$ genes was shown to be present in an extended chromatin state at the nuclear periphery of thymocytes (Kosak et al. 2002). To further investigate the discrepancy between distal and proximal $V_{H}$ gene recombination in $I^{\text {Pax } 5 /+}$ thymocytes, we next used three-color 3D FISH analysis (Skok et al. 2001) to localize different $\operatorname{IgH}$ gene segments in three-dimensionally (3D) preserved nuclei by confocal laser scanning microscopy (Fig. 5). The locations of the different $V_{H}$ and $C \gamma 1$ gene probes used are shown in Figure 5A together with the minimal number of base pairs separating these probes in the $\mathrm{IgH}$ locus.

As illustrated by the confocal images of Figure $5 \mathrm{~B}$, the distal $V_{H} J 558$ and $V_{H} 15$ genes were colocalized at the nuclear periphery in $92 \%-95 \%$ of all wild-type pro-T and pre-T cells (Fig. 5D), in agreement with published data (Kosak et al. 2002). The signals of the distal $V_{H}$ genes were separated in only $2 \%$ of all wild-type thymocytes (Fig. 5C). In marked contrast, the distal $V_{H}$ genes were separated from the proximal $V_{H} 7183$ and $C \gamma 1$ genes by a distance of $0.3-1.5 \mu \mathrm{m}$ in $89 \%-98 \%$ of the wild-type nuclei (Fig. 5C). In addition, the proximal $\mathrm{IgH}$ domain was positioned away from the nuclear periphery toward the center in $96 \%$ of wild-type pro-T and pre-T cells (Fig. 5B; data not shown). Hence, the $I g H$ locus is anchored via the distal $V_{H}$ genes at the nuclear periphery and is oriented in its extended chromatin state toward the center, which may facilitate access of the $\mathrm{V}(\mathrm{D}) \mathrm{J}$ recombinase to the proximal $I g H$ domain, thus accounting for the $D_{H}-J_{H}$ rearrangements observed in wild-type thymocytes.

Ectopic Pax5 expression resulted in subnuclear repositioning of the $I g H$ locus in pro- $\mathrm{T}$ and pre-T cells, as the majority $(62 \%)$ of $\operatorname{IgH}$ loci were located at central positions in the nuclei of $I k^{\text {Pax5/+ }}$ thymocytes (Fig. 5B,D). A similar percentage of centrally located $I g H$ alleles was observed in $\mathrm{RAG}^{-/-}$and $\mathrm{Pax}^{-/-} \mathrm{RAG}^{-/-}$pro-B cells (Figs. 5D, 6A), indicating that the relocation of the $\operatorname{IgH}$ locus is as efficient in $\mathrm{Ik}^{\mathrm{Pax} 5 /+}$ thymocytes as in pro-B cells. Importantly, the $\operatorname{IgH}$ locus remained in an extended chromatin state even in its more central location, as the distal $V_{H} J 558$ and $V_{H} 15$ genes were still separated from the proximal $V_{H} 7183$ and $C \gamma 1$ genes in $92 \%-100 \%$ of all $I k^{\text {Pax } 5 /+}$ pro-T and pre-T cells (Fig. 5C). The physical separation of distal $V_{H}$ genes from the rearranged $D I_{H}$ segment is therefore a likely cause for the low $V_{H}-D J_{H}$ recombination efficiency of distal $V_{H}$ genes in $I^{\text {Pax 5/+ }}$ thymocytes.

The IgH locus is present in an extended chromatin state in $\mathrm{Pax}^{-/-}$pro- $B$ cells

As the $\mathrm{Pax}^{-/-}$pro-B cells and $I k^{\text {Pax5/+ }}$ thymocytes exhibit a similar $V_{H^{-}}-D J_{H}$ recombination phenotype, we 
A

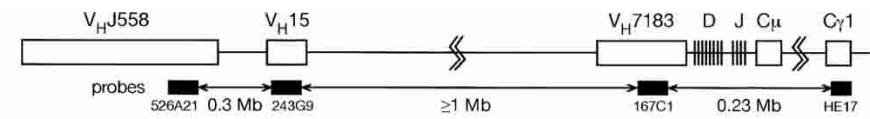

B
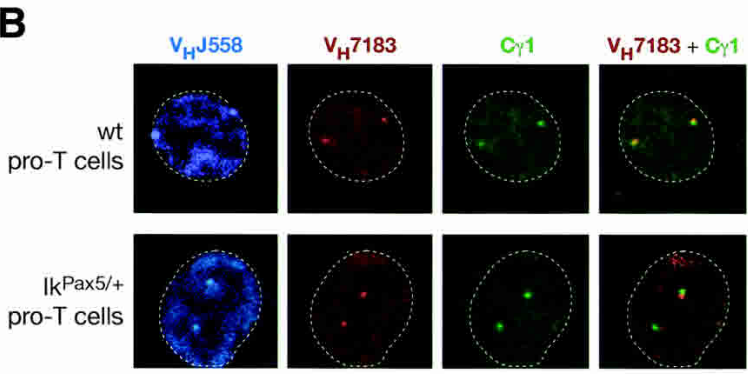

$V_{\mathrm{H}^{\mathrm{J}}} \mathrm{J558}$

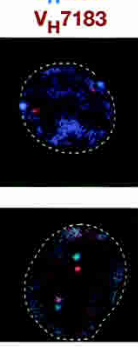

C separation of gene segments

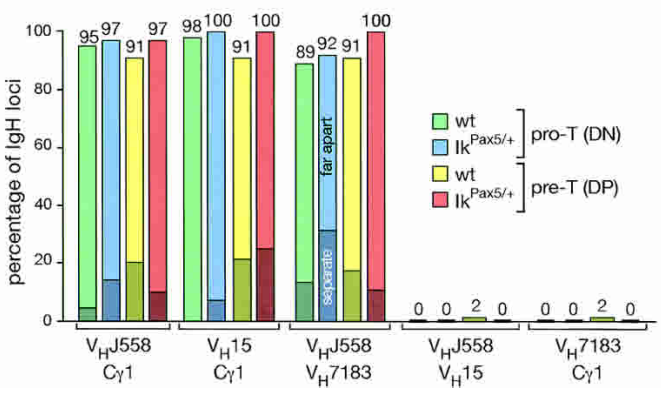

D nuclear periphery

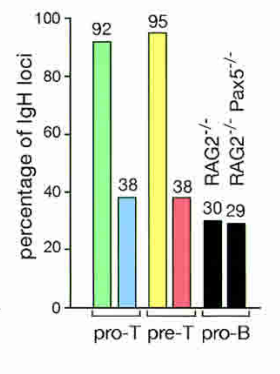

Figure 5. Subnuclear compartmentalization and extended chromatin state of $V_{H}$ genes in thymocyte nuclei. (A) Schematic diagram indicating the positions of the DNA probes in the $I g H$ locus (not drawn to scale). The minimal number of megabase pairs $(\mathrm{Mb})$ separating the probes was estimated according to the mouse genome database (Ensembl release of July 1, 2003). (B) Three-color 3 D DNA-FISH analysis of the $I g H$ locus. Confocal laser scanning microscopy identified the subnuclear locations of different gene segments of the two $\operatorname{IgH}$ alleles, which are shown on representative single optical sections through the nucleus of sorted wild-type (wt) and $I k^{P a x 5 /+}$ pro- $\mathrm{T}(\mathrm{DN})$ cells. The different probes with their colors are indicated. The $V_{H}$ 558 BAC (526A21) was directly labeled with Cy5-dUTP (blue). The $V_{H} 7183$ (167C1) BACs as well as $V_{H} 15(243 \mathrm{G} 9)$ BAC (not shown in panel $B$ ) were labeled with digoxygenin-dUTP and detected with rhodamine- and Texas red-coupled anti-digoxygenin antibodies (red). The $C_{\gamma} 1$ probe (HE17) was labeled with biotindUTP and detected with FITC-avidin and biotinylated FITC-coupled anti-avidin antibodies (green). The IRESGFP sequences, which were flanked by frt sites in the $I k^{P a x 5}$ allele (Souabni et al. 2002), were specifically deleted for the three-color FISH analysis by mating $I k^{P a x 5 /+}$ mice with the transgenic ACTB:FLPe deleter line (Rodriguez et al. 2000). The contour of the cell is indicated by a broken line. $(C)$ Statistical analysis of the distance between proximal and distal $V_{H}$ genes in thymocyte nuclei of the indicated genotypes. Signals of the different $I g H$ gene probes, which were separated in the nucleus by $0.3-0.5 \mu \mathrm{m}$ (separate; dark color) or 0.5-1.5 $\mu \mathrm{m}$ (far apart; light color), were scored as percentage of all signals analyzed. The actual numbers and sample sizes are shown in Supplementary Table 1A. (D) Statistical analysis of the peripheral location of distal $V_{H}$ genes in thymocytes and pro-B cells of the indicated genotypes. next studied the nuclear location and chromatin state of $\mathrm{IgH}$ loci in wild-type and $\mathrm{Pax}^{-/-}$pro-B cells. The $\operatorname{IgH}$ alleles were centrally located in $\sim 70 \%$ of the pro-B cell nuclei regardless of the presence or absence of Pax5 (Figs. $5 \mathrm{D}, 6 \mathrm{~A})$. Interestingly, the distal $V_{H} J 558$ and $V_{H} 15$ genes were separated from the proximal $V_{H} 7183$ and $C \gamma 1$ genes in $84 \%-94 \%$ of all $\mathrm{Pax}^{-/-}$pro-B cells (Fig. 6A,B), similar to the situation observed in $\mathrm{Ik}^{\text {Pax5/+ }}$ pro- $\mathrm{T}$ cells (Fig. $5 \mathrm{~B}, \mathrm{C})$. In contrast, the distal and proximal $\mathrm{IgH}$ gene segments were colocalized in $76 \%-86 \%$ of wild-type pro-B cells, whereas they were separated by only a short distance $(0.3-0.5 \mu \mathrm{m})$ in the remaining $14 \%-24 \%$ of pro-B cells (Fig. 6B). These data therefore point to an essential role for Pax5 in regulating large-scale contraction of the IgH locus. To rule out the possibility that this Pax 5 function depends on $V(D) J$ recombination, we analyzed $\mathrm{Pax}^{+/+}$and $\mathrm{Pax}^{-/-}$pro-B cells on a RAG2 mutant background, which prevents immunoglobulin gene rearrangements (Shinkai et al. 1992). The IgH locus was still in an extended state in $\mathrm{Pax}^{-/-} \mathrm{RAG2}^{-/-}$pro-B cells and in a contracted state in $\mathrm{Pax}^{+/+} \mathrm{RAG}^{-/-}$pro-B cells (Fig. 6A,B), indicating that Pax5-mediated contraction of the $I g H$ locus can precede $V(D) J$ recombination in pro-B cells.
Pax5 induces $\mathrm{IgH}$ locus contraction and distal $\mathrm{V}_{\mathrm{H}}-\mathrm{DJ} \mathrm{J}_{\mathrm{H}}$ rearrangements in pro- $B$ cells

To directly demonstrate an involvement of Pax5 in $\operatorname{IgH}$ locus contraction and distal $V_{H}-D J_{H}$ recombination, we used retroviral infection to restore Pax 5 expression in in vitro cultured $\mathrm{Pax}^{-/-}$pro-B cells. The retrovirus M-Pax5-iCD2 as well as the parental virus MiCD2 (Heavey et al. 2003) express a human CD2 indicator protein, which facilitated FACS sorting of the infected cells prior to PCR quantification of $I g H$ rearrangements (Fig. 7A). $D_{H}-J_{H}$ and proximal $V_{H} 7183-D J_{H}$ rearrangements were present at similar levels in $\mathrm{Pax}^{-/-}$pro-B cells regardless of whether these cells were infected with the parental or Pax5-expressing virus (Fig. 7A). In contrast, retroviral Pax5 expression led to a 10-fold increase of distal $V_{H} J 558-D J_{H}$ recombination above the level seen in in vitro cultured $\mathrm{Pax}^{-/-}$pro-B cells (Fig. 7A). We next infected double-mutant $\mathrm{Pax}^{-1-} \mathrm{RAG2^{-/- }}$ pro-B cells to study the effect of $P a x 5$ on $I g H$ locus contraction in the absence of $V(D) J$ recombination. As expected, the distal $V_{H} J 558$ and $V_{H} 15$ genes were separated from the proximal $V_{H} 7183$ and $C \gamma 1$ genes in $94 \%-96 \%$ of the $\mathrm{Pax}^{-/-}$ $R A G 2^{-/-}$pro-B cells infected with the parental MiCD2 


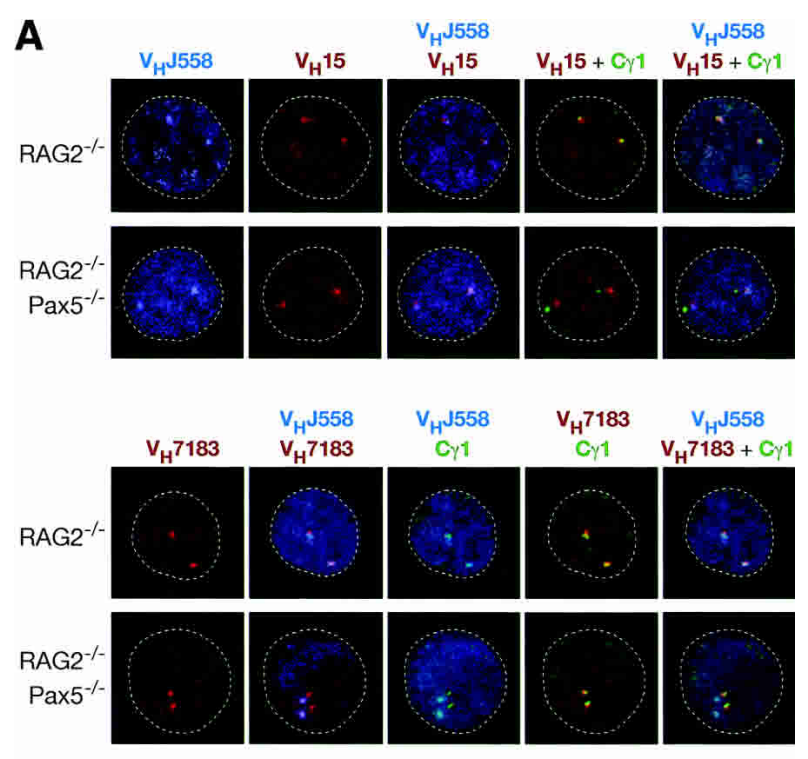

B

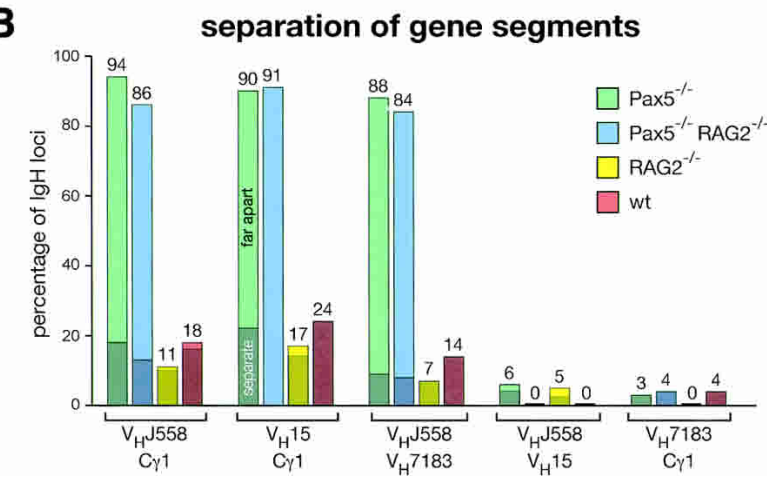

Figure 6. Absence of $\operatorname{IgH}$ locus contraction in the nucleus of $\mathrm{Pax}^{-/-}$pro-B cells. (A) Three-color 3D DNA-FISH analysis of the $\mathrm{IgH}$ locus. In vitro cultured $\mathrm{RAG2^{-/- }}$ and $\mathrm{Pax}^{-/-} \mathrm{RAG2^{-/- }}$ pro-B cells were analyzed by FISH and confocal microscopy as described in the legend for Figure 5B. $(B)$ Statistical analysis of the distance between proximal and distal $V_{H}$ genes in pro-B cells of the indicated genotypes. A distance of $0.3-0.5 \mu \mathrm{m}$ (separate) or $0.5-1.5 \mu \mathrm{m}$ (far apart) between the signals is indicated by dark or light color, respectively. See Supplementary Table 1B for further information.

virus (Fig. 7B,C). In contrast, both distal and proximal gene segments were colocalized and thus present in a contracted state in $69 \%-75 \%$ of the Pax5-reconstituted $\mathrm{Pax}^{-/-}$RAG2 $2^{-/-}$pro-B cells, which compares favorably with the corresponding frequency $(83 \%-93 \%)$ observed in $\mathrm{Pax}^{+/+} \mathrm{RAG}^{-/-}$pro-B cells (Fig. $7 \mathrm{~B}, \mathrm{C}$ ). We conclude therefore that Pax5 facilitates distal $V_{H}-D J_{H}$ rearrangements by inducing IgH locus contraction in pro-B cells.

\section{Discussion}

Previous loss-of-function analyses identified an essential role for Pax5 in controlling $V_{H}-D J_{H}$ recombination of distal but not proximal $V_{H}$ genes in pro-B cells (Nutt et al. 1997; Hesslein et al. 2003). Here we have reported the unexpected finding that ectopic expression of Pax5 promotes efficient rearrangement of proximal rather than distal $V_{H}$ genes in pro-T cells. The distal $V_{H} / 558$ genes are, however, present in accessible chromatin in $I k^{\text {Pax 5/+ }}$ pro-T cells similar to $\mathrm{Pax}^{-/-}$pro-B cells. Hence, the loss of Pax5 in pro-B cells results in the same $V_{H^{-}}-D I_{H}$ recombination phenotype as expression of Pax 5 in pro-T cells. This phenotypic similarity was further extended by FISH analyses demonstrating that the $I g H$ loci in both cell types are located at central positions of the nucleus and are present in an extended chromatin state (Fig. 7D). As a consequence, the distal $V_{H}$ genes are separated from the proximal $I g H$ domain by a large distance, which is likely to prevent efficient synapse formation between distal and proximal gene segments, thus resulting in a dramatic reduction of distal $V_{H}-D J_{H}$ recombination in both cell types (Fig. 7D). The seemingly conflicting data of the Pax5 gain- and loss-of-function analyses may be explained by the existence of an unknown factor $\mathrm{X}$ that is expressed in B cells but not in T cells and that cooperates with Pax5 in the control of locus contraction and distal $V_{H}-D I_{H}$ rearrangements (Fig. 7D). According to this hypothesis, the absence of factor $\mathrm{X}$ in $I k^{\text {Pax } 5 /+}$ pro- $\mathrm{T}$ cells or the loss of Pax 5 in $\mathrm{Pax}^{-/-}$pro-B cells results in equally inefficient recombination of distal $V_{H}$ genes. Importantly, the restoration of Pax5 expression in $\mathrm{Pax}^{-/-}$ pro-B cells unequivocally demonstrated that Pax 5 promotes distal $V_{H}-D J_{H}$ recombination by inducing largescale contraction of the $I g H$ locus, which leads to juxtaposition of distal $V_{H}$ genes next to the proximal $D_{H} J_{H^{-}}$ rearranged gene segment.

The IgH locus contains 150-200 $V_{H}$ genes, which are positioned over a chromosomal region of $\sim 3 \mathrm{Mb}$ (Chevillard et al. 2002). The large size of the $I g H$ locus is likely to constitute a mechanistic constraint for $V(D) J$ recombination, as synapse formation between the distal $V_{H}$ genes and proximal $D_{H} J_{H}$-rearranged gene segment may be ineffective, resulting in a lower efficiency of $V_{H}-D J_{H}$ recombination for distal relative to proximal $V_{H}$ genes. Indeed, $V_{H}-D J_{H}$ recombination exhibits a marked preference for the utilization of the most proximal $V_{H}$ genes both in fetal and adult B-lymphopoiesis (Yancopoulos et al. 1984; Malynn et al. 1990). Even within the proximal $V_{H} 7183$ family, the more proximally located $V_{H}$ genes are preferentially used for $V(D) J$ recombination (Williams et al. 2001). This position-dependent bias in $V_{H}$ gene rearrangements is observed already in wild-type pro-B cells, but is dramatically increased in the absence of Pax5, as $\mathrm{Pax}^{-/-}$pro-B cells essentially fail to undergo distal $V_{H}-D J_{H}$ recombination (Nutt et al. 1997). The recently published FISH analysis of Kosak et al. (2002) provided the first evidence that $V(D) J$ recombination may be controlled by the subnuclear location and contraction state of the $I g H$ locus. Our detailed $V(D) J$ recombination and 3D FISH analyses have now considerably extended these published data by implicating the two B-cell-specific transcription factors EBF and Pax5 in controlling two separate steps of $\operatorname{IgH}$ locus activation. As illustrated by the two-step model in Figure 7D, the $\operatorname{IgH}$ locus is 


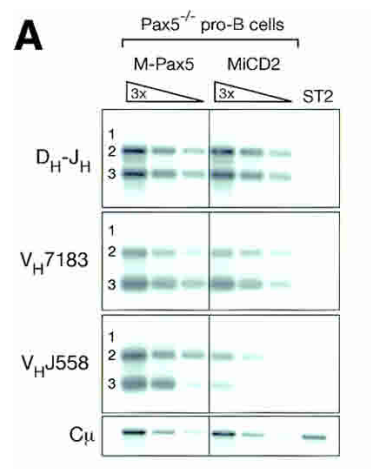

C

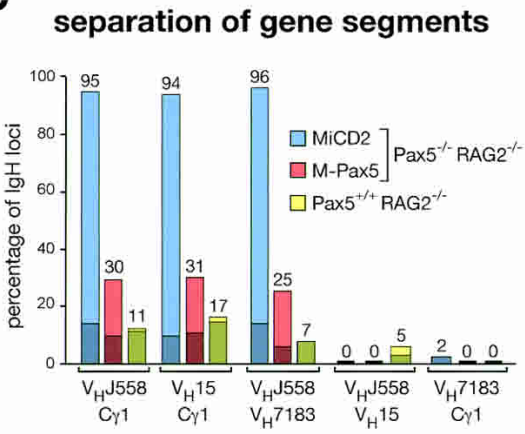

B
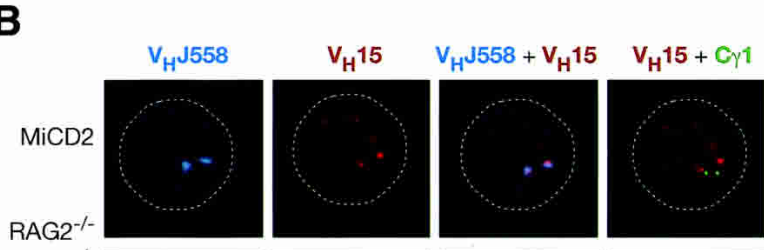

$\mathrm{V}_{\mathrm{H}} \mathrm{J} 558$

$\mathrm{Pax}^{-1}$
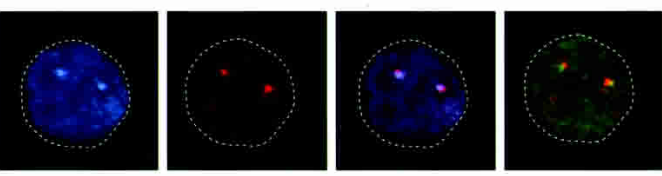

$\mathrm{V}_{\mathrm{H}^{15}} 15+\mathrm{C}_{\gamma^{1}}$

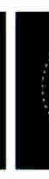

ค. :

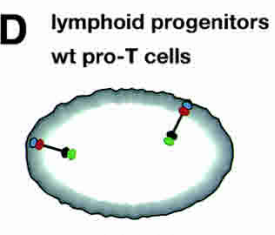

no $V_{H^{-}}-D J_{H}$
Pax $5^{-1-}$ pro-B cells Ik ${ }^{\text {Pax } 5 /+}$ pro-T cells

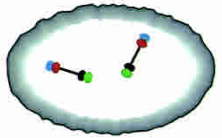

proximal $\mathrm{V}_{\mathrm{H}^{-}}-\mathrm{DJ} \mathrm{J}_{\mathrm{H}}$

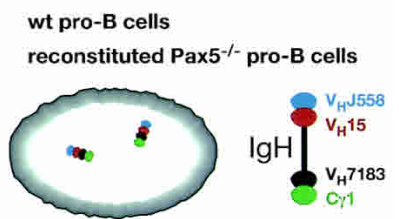

distal + proximal $\mathrm{V}_{\mathrm{H}^{-}}-\mathrm{DJ} \mathrm{J}_{\mathrm{H}}$ subnuclear relocation

locus contraction

anchored via the distal $V_{H}$ genes at the nuclear periphery and is oriented in its extended chromatin state toward the center of the nucleus in all non-B cells such as pro- $T$ cells. In this default configuration of the $I g H$ locus, the distal $V_{H}$ genes are likely to be silenced, as the nuclear periphery may function as a repressive compartment in higher eukaryotes in analogy to yeast (Baxter et al. 2002; Hediger and Gasser 2002). The more centrally located, proximal $\operatorname{IgH}$ domain may, however, be accessible for the V(D)J recombinase, which could account for the low level of $D_{H}-J_{H}$ rearrangements observed in thymocytes and dendritic cells (Kurosawa et al. 1981; Corcoran et al. 2003). The first step of $\operatorname{IgH}$ locus activation consists of relocation of the $\mathrm{IgH}$ locus from the nuclear periphery to a central position within the nucleus (Fig. 7D). In the absence of locus contraction, this subnuclear repositioning in concert with chromatin changes leads to proximal $V_{H}-D J_{H}$ rearrangements as observed in $I^{\text {Pax5/+ }}$ pro- $\mathrm{T}$ cells and $\mathrm{Pax}^{-/-}$pro-B cells. Interestingly, the subnuclear relocation of the $\operatorname{IgH}$ locus correlates with expression of the B-cell-specific transcription factor EBF in both cell types. EBF is known to function upstream of Pax5 in early B-lymphopoiesis, as it is normally expressed in a Pax5-independent manner in $\mathrm{Pax}^{-/-}$pro-B cells (Nutt et al. 1997). Unexpectedly, ectopic expression of Pax5 activates EBF in $I k^{P a x 5 /+}$ pro-T cells, thus identifying a novel cross-regulatory interaction between these two transcription factors. Based on the correlation between $E B F$ expression and $I g H$ relocation, we hypothesize that EBF may be involved in controlling the first step of $I g H$ locus activation. In a second step, Pax5 together with factor $\mathrm{X}$ induces $\operatorname{Ig} H$ locus contraction and distal $V_{H}-D J_{H}$ rearrangements in wild-type pro-B cells (Fig. 7D).

Another important regulatory step in $V(D) J$ recombination controls the accessibility of the $\operatorname{IgH}$ locus (Yancopoulos and Alt 1985), which is determined by the local chromatin structure of the different gene segments (Stanhope-Baker et al. 1996; Maes et al. 2001). Histone acetylation, which is a characteristic feature of open chromatin, plays an important role in determining the chromatin accessibility of $I g$ and TCR loci (Chowdhury and Sen 2001; Krangel 2003). Analysis of the histone acetylation state revealed a stepwise activation of discrete chromatin domains in the $\mathrm{IgH}$ locus (Chowdhury and Sen 2001). A 120-kb genomic region encompassing the $D_{H}, J_{H}$ and $C \mu$ gene segments is first hyperacetylated prior to $V(D) J$ recombination. $D_{H}-J_{H}$ rearrangements 
subsequently induce histone acetylation and rearrangements of the proximal $V_{H}$ genes (Chowdhury and Sen 2001). Finally, the distal $2-\mathrm{Mb}$ domain containing the majority of $V_{H}$ genes is activated by IL-7 signaling (Chowdhury and Sen 2001) consistent with the observation that $V_{H}-D I_{H}$ recombination of the distal, but not proximal $V_{H}$ genes is severely impaired in B-cell progenitors of $I L-7 R \alpha^{-/-}$mice (Corcoran et al. 1998). Despite the similar recombination phenotype of $I L-7 R \alpha^{-/-}$pro-B cells and $\mathrm{Ik}^{\mathrm{Pax} 5 /+}$ thymocytes, we do not regard IL-7 signaling to be the missing component in $\mathrm{T}$ cells that normally cooperates with Pax5 in the control of distal $V_{H^{-}}$ $D I_{H}$ rearrangements for the following reasons. First, IL-7 signaling is active during early T-cell development, where it plays an essential role in regulating cell proliferation and survival (Fry and Mackall 2002). Second, the expression of germ-line $V_{H} / 558$ transcripts in $\mathrm{Ik}^{\text {Pax } 5 /+}$ pro- $\mathrm{T}$ cells indicates that the distal $\mathrm{IgH}$ domain is present in an accessible chromatin state (Fig. 4C), which is likely established under the influence of IL-7 signaling (Chowdhury and Sen 2001). Finally, the incubation of sorted $I k^{\text {Pax 5/+ }}$ pro-T cells in IL-7 medium for $2 \mathrm{~d}$ failed to promote distal $V_{H}-D I_{H}$ rearrangements (M. Fuxa and M. Busslinger, unpubl.). Based on these considerations, we hypothesize that the recombination of distal $V_{H}$ genes is controlled by two independent pathways. IL-7 signaling is essential for the establishment of an accessible chromatin state in the distal $\operatorname{IgH}$ domain, whereas a second Pax5-dependent pathway is responsible for contraction of the activated $V_{H}$ locus, thus leading to distal $V_{H^{-}}-D I_{H}$ rearrangements.

It is important to note that the Pax5-dependent contraction of the $I g H$ locus occurs under conditions that do not affect the accessible chromatin state of the $V_{H}$ genes. Hence, locus contraction cannot be caused by chromatin condensation of the entire IgH locus. Interestingly, histone acetylation and thus chromatin accessibility are narrowly confined to individual $V_{H}$ gene segments, their promoters and RSS sites (Johnson et al. 2003). It is, therefore, conceivable that the intergenic regions between $V_{H}$ genes contain regulatory elements that control locus contraction. An interesting paradigm for such regulatory sequences are the Polycomb response elements (PREs), which have the potential to form clusters with each other through the binding of Polycomb group (PcG) proteins (Pirrotta 1998; Francis and Kingston 2001; Orlando 2003). In apparent conflict with a possible role in locus contraction, the PcG proteins are generally thought to function in gene repression by maintaining the transcriptionally silent state (Pirrotta 1998; Francis and Kingston 2001; Orlando 2003). Interestingly however, the histone methyltransferase Ezh2 is not only a member of the PcG protein family, but is also an essential regulator of distal $V_{H^{-}}-D J_{H}$ rearrangements (Su et al. 2003). Ezh2 and its related gene Ezh1 are similarly expressed at early stages of B- and T-cell development, as demonstrated by RTPCR analysis of pro-B cells and immature thymocytes (Fig. 4C). Hence, Ezh1 and Ezh2 are unlikely candidates for factor X, which could, however, be another PcG protein that is expressed in pro-B cells, but not in thymo- cytes. We are presently testing the hypothesis that Pax5 cooperates with the PcG system in controlling IgH locus contraction and distal $V_{H}-D I_{H}$ rearrangements. It is, however, also conceivable that ectopic Pax5 expression in $I k^{P a x 5 /+}$ thymocytes fails to properly activate a Pax5 target gene, which codes for a chromatin regulator mediating $I g H$ locus contraction.

\section{Materials and methods}

\section{Mice}

$I k^{\mathrm{Pax} 5 /+}$ and $I k^{\mathrm{neo} /+}$ (Souabni et al. 2002), $\mathrm{Pax}^{-/-}$(Nutt et al. 1997), RAG2 $2^{-/-}$(Shinkai et al. 1992), and lck-cre mice (Lee et al. 2001) were maintained and genotyped as described.

\section{FACS sorting and analysis}

The following phycoerythrin (PE)- or allophycocyanin (APC)coupled antibodies were used for flow cytometry: anti-B220 (RA3-6B2), CD4 (L3T4), CD8 (53-6.7), CD11c (HL3), CD19 (1D3), DX5 (DX5), Gr-1 (RB6-8C5), c-Kit (2B8), IgM (M41.42), Mac-1 (M1/70), TCR $\beta$ (H57-597), Ter119 (TER-119), and Thy 1.2 (30-H12) antibodies. Unspecific antibody binding was suppressed by preincubation of cells with CD16/CD32 Fc-block solution (PharMingen). Intracellular staining of cytoplasmic Ig $\mu$ protein was performed as described (Thévenin et al. 1998). Pro-B cells were sorted as $\mathrm{B} 22 \mathrm{O}^{+} \mathrm{c}-\mathrm{Kit}^{+}$cells after enrichment of c-Kit ${ }^{+}$ bone marrow cells by magnetic cell sorting (MACS). DP thymocytes were sorted as $\mathrm{CD} 4^{+} \mathrm{CD}^{+}$cells after depletion of $\mathrm{B} 220^{+}$cells. DN thymocytes were sorted as Thy $1.2^{+} \mathrm{Lin}^{-}$cells following depletion of $\mathrm{Lin}^{+}$cells (stained with PE-anti-B220, CD4, CD8, DX5, CD11c, Mac-1, Gr-1, and Ter119 antibodies) with anti-PE MACS beads (Miltenyi Biotec).

\section{$\mathrm{V}(\mathrm{D})$ J recombination analysis}

Sorted cells from 2-week-old mice were digested with proteinase $\mathrm{K}$, and DNA was isolated by phenol extraction and ethanol precipitation. PCR analyses of immunoglobulin genes were performed with published primers (Supplementary Table 2) as described (Schlissel et al. 1991; Angelin-Duclos and Calame 1998). $T C R \beta$ rearrangements were analyzed as described (Wolfer et al. 2002). PCR cycle numbers were adjusted to be in the linear range, based on the analysis of serially diluted DNA. PCR products were separated on agarose gels, transferred to a porablot NYamp membrane and analyzed by Southern blotting using published oligonucleotide probes (Supplementary Table 2; Schlissel et al. 1991).

\section{RT-PCR analysis}

RNA was prepared from sorted cells, using the Trizol Reagent (GIBCO-BRL). Reverse transcription (with random hexamers) and semiquantitative PCR were performed as described (Horcher et al. 2001), using the primers shown in Supplementary Table 3. PCR products were separated on agarose gels and visualized by ethidium bromide.

\section{D DNA-FISH and confocal analysis}

Three-color 3D FISH experiments were carried out with sorted pro-T and pre- $\mathrm{T}$ cells as well as with in vitro cultured pro-B cells as previously described in detail (Skok et al. 2001). The fixation 
conditions used were designed to preserve nuclear integrity (Skok et al. 2001). Cells were analyzed by confocal microscopy on a Leica SP2 AOBS (Acousto Optical Beam Splitter) system. Optical Z-sections were collected at $0.3-\mu \mathrm{m}$ steps through individual nuclei. Only cells containing signals of both $I g H$ loci were evaluated. DNA probes were prepared from the BACs 526A21 $\left(V_{H} / 558\right), 243 \mathrm{G} 9\left(V_{H} 10\right)$, and 167C1 $\left(V_{H} 7183\right.$; Kosak et al. 2002), as well as from the plasmid p $\gamma 1 / \mathrm{HE} 17$ containing a 17-kb genomic insert of the $C \gamma 1$ region (Skok et al. 2001). The distance between the signals of the different $I g H$ gene probes in the nucleus was measured on individual confocal images. A distance of $0.3-0.5 \mu \mathrm{m}$ was evaluated as "separate," whereas "far apart" referred to a distance of 0.5-1.5 $\mu \mathrm{m}$ (Supplementary Table 1; Figs. 5-7).

\section{Retroviral infection of pro-B cells}

A human Pax 5 cDNA was inserted upstream of the IRES-hCD2t gene of the retroviral vector MiCD2, which results in expression of a C-terminally truncated $(\mathrm{t})$ human $(\mathrm{h}) \mathrm{CD} 2$ indicator protein (Heavey et al. 2003). The M-Pax5-iCD2 virus was generated and used for infection of $\mathrm{Pax}^{-{ }^{--}}$and $\mathrm{Pax}^{-{ }^{--}} \mathrm{RAG2^{-/- }}$ pro-B cells as described (Heavey et al. 2003). Pax 5 expression was verified by Western blot analysis of infected pro-B cells.

\section{Acknowledgments}

We thank C. Wilson for providing the lck-cre transgenic mouse, D. Hesslein for advice on rearrangement PCR assays, and G. Stengl for FACS sorting. This research was supported by Boehringer Ingelheim, the Austrian GEN-AU initiative (financed by BMBWK), and a Wellcome Trust University Award (J.S.).

The publication costs of this article were defrayed in part by payment of page charges. This article must therefore be hereby marked "advertisement" in accordance with 18 USC section 1734 solely to indicate this fact.

\section{References}

Adams, B., Dörfler, P., Aguzzi, A., Kozmik, Z., Urbánek, P., Maurer-Fogy, I., and Busslinger, M. 1992. Pax-5 encodes the transcription factor BSAP and is expressed in B lymphocytes, the developing CNS, and adult testis. Genes \& Dev. 6: 15891607.

Allman, D., Sambandam, A., Kim, S., Miller, J.P., Pagan, A., Well, D., Meraz, A., and Bhandoola, A. 2003. Thymopoiesis independent of common lymphoid progenitors. Nat. Immunol. 4: 168-174.

Angelin-Duclos, C. and Calame, K. 1998. Evidence that immunoglobulin $\mathrm{V}_{\mathrm{H}}$-DJ recombination does not require germ line transcription of the recombining variable gene segment. Mol. Cell. Biol. 18: 6253-6264.

Bain, G., Maandag, E.C.R., Izon, D.J., Amsen, D., Kruisbeek, A.M., Weintraub, B.C., Krop, I., Schlissel, M.S., Feeney, A.J., van Roon, M., et al. 1994. E2A proteins are required for proper B cell development and initiation of immunoglobulin gene rearrangements. Cell 79: 885-892.

Bassing, C.H., Swat, W., and Alt, F.W. 2002. The mechanism and regulation of chromosomal V(D)J recombination. Cell 109 Suppl.: S45-S55.

Baxter, J., Merkenschlager, M., and Fisher, A.G. 2002. Nuclear organisation and gene expression. Curr. Opin. Cell Biol. 14: $372-376$.

Born, W., White, J., Kappler, J., and Marrack, P. 1988. Rearrangement of IgH genes in normal thymocyte development. J. Im- munol. 140: 3228-3232.

Burrows, P.D., Stephan, R.P., Wang, Y.H., Lassoued, K., Zhang, Z., and Cooper, M.D. 2002. The transient expression of pre-B cell receptors governs B cell development. Semin. Immunol. 14: 343-349.

Busslinger, M., Klix, N., Pfeffer, P., Graninger, P.G., and Kozmik, Z. 1996. Deregulation of $P A X-5$ by translocation of the E $\mu$ enhancer of the $I g H$ locus adjacent to two alternative $P A X-5$ promoters in a diffuse large-cell lymphoma. Proc. Natl. Acad. Sci. 93: 6129-6134.

Chevillard, C., Ozaki, J., Herring, C.D., and Riblet, R. 2002. A three-megabase yeast artificial chromosome contig spanning the C57BL mouse Igh locus. J. Immunol. 168: 5659-5666.

Chowdhury, D. and Sen, R. 2001. Stepwise activation of the immunoglobulin $\mu$ heavy chain gene locus. EMBO J. 20: 6394-6403.

Corcoran, A.E., Riddell, A., Krooshoop, D., and Venkitaraman, A.R. 1998. Impaired immunoglobulin gene rearrangement in mice lacking the IL-7 receptor. Nature 391: 904-907.

Corcoran, L., Ferrero, I., Vremec, D., Lucas, K., Waithman, J., O'Keeffe, M., Wu, L., Wilson, A., and Shortman, K. 2003. The lymphoid past of mouse plasmacytoid cells and thymic dendritic cells. J. Immunol. 170: 4926-4932.

Francis, N.J. and Kingston, R.E. 2001. Mechanisms of transcriptional memory. Nat. Rev. Mol. Cell Biol. 2: 409-421.

Fry, T.J. and Mackall, C.L. 2002. Interleukin-7: From bench to clinic. Blood 99: 3892-3904.

Heavey, B., Charalambous, C., Cobaleda, C., and Busslinger, M. 2003. Myeloid lineage switch of Pax5 mutant but not wildtype $\mathrm{B}$ cell progenitors by $\mathrm{C} / \mathrm{EBP} \alpha$ and GATA factors. $E M B O$ J. 22: 3887-3897.

Hediger, F. and Gasser, S.M. 2002. Nuclear organization and silencing: Putting things in their place. Nat. Cell Biol. 4: E53-E55.

Hesslein, D.G. and Schatz, D.G. 2001. Factors and forces controlling V(D)J recombination. Adv. Immunol. 78: 169-232.

Hesslein, D.G.T., Pflugh, D.L., Chowdhury, D., Bothwell, A.L.M., Sen, R., and Schatz, D.G. 2003. Pax5 is required for recombination of transcribed, acetylated, 5' IgH V gene segments. Genes \& Dev. 17: 37-42.

Horcher, M., Souabni, A., and Busslinger, M. 2001. Pax5/BSAP maintains the identity of $\mathrm{B}$ cells in late B lymphopoiesis. Immunity 14: 779-790.

Igarashi, H., Gregory, S.C., Yokota, T., Sakaguchi, N., and Kincade, P.W. 2002. Transcription from the RAG1 locus marks the earliest lymphocyte progenitors in bone marrow. Immunity 17: 117-130.

Johnson, K., Angelin-Duclos, C., Park, S., and Calame, K.L. 2003. Changes in histone acetylation are associated with differences in accessibility of $\mathrm{V}_{\mathrm{H}}$ gene segments to $\mathrm{V}-\mathrm{DJ}$ recombination during B-cell ontogeny and development. Mol. Cell. Biol. 23: 2438-2450.

Kondo, M., Weissman, I.L., and Akashi, K. 1997. Identification of clonogenic common lymphoid progenitors in mouse bone marrow. Cell 91: 661-672.

Kosak, S.T., Skok, J.A., Medina, K.L., Riblet, R., Le Beau, M.M., Fisher, A.G., and Singh, H. 2002. Subnuclear compartmentalization of immunoglobulin loci during lymphocyte development. Science 296: 158-162.

Krangel, M.S. 2003. Gene segment selection in V(D)J recombination: Accessibility and beyond. Nat. Immunol. 4: 624-630.

Kurosawa, Y., von Boehmer, H., Haas, W., Sakano, H., Trauneker, A., and Tonegawa, S. 1981. Identification of D segments of immunoglobulin heavy-chain genes and their rearrangement in T lymphocytes. Nature 290: 565-570. 
Lee, P.P., Fitzpatrick, D.R., Beard, C., Jessup, H.K., Lehar, S., Makar, K.W., Perez-Melgosa, M., Sweetser, M.T., Schlissel, M.S., Nguyen, S., et al. 2001. A critical role for Dnmt1 and DNA methylation in T cell development, function, and survival. Immunity 15: 763-774.

Li, Y.-S., Hayakawa, K., and Hardy, R.R. 1993. The regulated expression of B lineage-associated genes during B cell differentiation in bone marrow and fetal liver. J. Exp. Med. 178: 951-960.

Lin, H. and Grosschedl, R. 1995. Failure of B-cell differentiation in mice lacking the transcription factor EBF. Nature 376: 263-267.

Maes, J., O'Neill, L.P., Cavelier, P., Turner, B.M., Rougeon, F., and Goodhardt, M. 2001. Chromatin remodeling at the Ig loci prior to $\mathrm{V}(\mathrm{D}) \mathrm{J}$ recombination. J. Immunol. 167: 866-874.

Malynn, B.A., Yancopoulos, G.D., Barth, J.E., Bona, C.A., and Alt, F.W. 1990. Biased expression of $J_{H}$-proximal $V_{H}$ genes occurs in the newly generated repertoire of neonatal and adult mice. J. Exp. Med. 171: 843-859.

Nutt, S.L., Urbánek, P., Rolink, A., and Busslinger, M. 1997. Essential functions of Pax5 (BSAP) in pro-B cell development: Difference between fetal and adult B lymphopoiesis and reduced $V$-to- $D J$ recombination at the $I g H$ locus. Genes \& Dev. 11: 476-491.

Nutt, S.L., Morrison, A.M., Dörfler, P., Rolink, A., and Busslinger, M. 1998. Identification of BSAP (Pax-5) target genes in early B-cell development by loss- and gain-of-function experiments. EMBO T. 17: 2319-2333.

Nutt, S.L., Heavey, B., Rolink, A.G., and Busslinger, M. 1999. Commitment to the B-lymphoid lineage depends on the transcription factor Pax5. Nature 401: 556-562.

O'Riordan, M. and Grosschedl, R. 1999. Coordinate regulation of $\mathrm{B}$ cell differentiation by the transcription factors EBF and E2A. Immunity 11: 21-31.

Orlando, V. 2003. Polycomb, epigenomes, and control of cell identity. Cell 112: 599-606.

Pirrotta, V. 1998. Polycombing the genome: PcG, trxG, and chromatin silencing. Cell 93: 333-336.

Rodriguez, C.I., Buchholz, F., Galloway, J., Sequerra, R., Kasper, J., Ayala, R., Stewart, A.F., and Dymecki, S.M. 2000. Highefficiency deleter mice show that FLPe is an alternative to Cre-loxP. Nat. Genet. 25: 139-140.

Rolink, A.G., Nutt, S.L., Melchers, F., and Busslinger, M. 1999. Long-term in vivo reconstitution of T-cell development by Pax5-deficient B-cell progenitors. Nature 401: 603-606.

Romanow, W.J., Langerak, A.W., Goebel, P., Wolvers-Tettero, I.L.M., van Dongen, J.J.M., Feeney, A.J., and Murre, C. 2000. $\mathrm{E} 2 \mathrm{~A}$ and $\mathrm{EBF}$ act in synergy with the $\mathrm{V}(\mathrm{D}) \mathrm{J}$ recombinase to generate a diverse immunoglobulin repertoire in nonlymphoid cells. Mol. Cell 5: 343-353.

Schebesta, M., Heavey, B., and Busslinger, M. 2002a. Transcriptional control of B cell development. Curr. Opin. Immunol. 14: $216-223$.

Schebesta, M., Pfeffer, P.L., and Busslinger, M. 2002b. Control of pre-BCR signaling by Pax5-dependent activation of the BLNK gene. Immunity 17: 473-485.

Schlissel, M.S., Corcoran, L.M., and Baltimore, D. 1991. Virustransformed pre-B cells show ordered activation but not inactivation of immunoglobulin gene rearrangement and transcription. J. Exp. Med. 173: 711-720.

Shinkai, Y., Rathbun, G., Lam, K.-P., Oltz, E.M., Stewart, V., Mendelsohn, M., Charron, J., Datta, M., Young, F., Stall, A.M., et al. 1992. RAG-2-deficient mice lack mature lymphocytes owing to inability to initiate $\mathrm{V}(\mathrm{D}) \mathrm{J}$ rearrangement. Cell 68: 855-867.

Sigvardsson, M., O'Riordan, M., and Grosschedl, R. 1997. EBF and E47 collaborate to induce expression of the endogenous immunoglobulin surrogate light chain genes. Immunity 7: 25-36.

Sigvardsson, M., Clark, D.R., Fitzsimmons, D., Doyle, M., Akerblad, P., Breslin, T., Bilke, S., Li, R., Yeamans, C., Zhang, G., and Hagman, J. 2002. Early B-cell factor, E2A, and Pax-5 cooperate to activate the early B cell-specific $m b-1$ promoter. Mol. Cell. Biol. 22: 8539-8551.

Skok, J.A., Brown, K.E., Azuara, V., Caparros, M.L., Baxter, J., Takacs, K., Dillon, N., Gray, D., Perry, R.P., Merkenschlager, M., et al. 2001. Nonequivalent nuclear location of immunoglobulin alleles in B lymphocytes. Nat. Immunol. 2: $848-854$

Souabni, A., Cobaleda, C., Schebesta, M., and Busslinger, M. 2002. Pax5 promotes B lymphopoiesis and blocks T cell development by repressing Notch1. Immunity 17: 781-793.

Stanhope-Baker, P., Hudson, K.M., Shaffer, A.L., Constantinescu, A., and Schlissel, M.S. 1996. Cell type-specific chromatin structure determines the targeting of $\mathrm{V}(\mathrm{D}) \mathrm{J}$ recombinase activity in vitro. Cell 85: 887-897.

Su, I.H., Basavaraj, A., Krutchinsky, A.N., Hobert, O., Ullrich, A., Chait, B.T., and Tarakhovsky, A. 2003. Ezh2 controls B cell development through histone $\mathrm{H} 3$ methylation and $I g h$ rearrangement. Nat. Immunol. 4: 124-131.

Thévenin, C., Nutt, S.L., and Busslinger, M. 1998. Early function of Pax5 (BSAP) prior to the pre-B cell receptor stage of B lymphopoiesis. J. Exp. Med. 188: 735-744.

Tonegawa, S. 1983. Somatic generation of antibody diversity. Nature 302: 575-581.

Traver, D., Akashi, K., Manz, M., Merad, M., Miyamoto, T., Engleman, E.G., and Weissman, I.L. 2000. Development of $\mathrm{CD} 8 \alpha$-positive dendritic cells from a common myeloid progenitor. Science 290: 2152-2154.

Urbánek, P., Wang, Z.-Q., Fetka, I., Wagner, E.F., and Busslinger, M. 1994. Complete block of early B cell differentiation and altered patterning of the posterior midbrain in mice lacking Pax5/BSAP. Cell 79: 901-912.

Wang, H., Diamond, R.A., and Rothenberg, E.V. 1998. Crosslineage expression of Ig- $\beta$ (B29) in thymocytes: Positive and negative gene regulation to establish $\mathrm{T}$ cell identity. Proc. Nat1. Acad. Sci. 95: 6831-6836.

Williams, G.S., Martinez, A., Montalbano, A., Tang, A., Mauhar, A., Ogwaro, K.M., Merz, D., Chevillard, C., Riblet, R., and Feeney, A.J. 2001. Unequal $\mathrm{V}_{\mathrm{H}}$ gene rearrangement frequency within the large $\mathrm{V}_{\mathrm{H}} 7183$ gene family is not due to recombination signal sequence variation, and mapping of the genes shows a bias of rearrangement based on chromosomal location. J. Immunol. 167: 257-263.

Wolfer, A., Wilson, A., Nemir, M., MacDonald, H.R., and Radtke, F. 2002. Inactivation of Notch1 impairs VDJ $\beta$ rearrangement and allows pre-TCR-independent survival of early $\alpha \beta$ lineage thymocytes. Immunity 16: 869-879.

Yancopoulos, G.D. and Alt, F.W. 1985. Developmentally controlled and tissue-specific expression of unrearranged $\mathrm{V}_{\mathrm{H}}$ gene segments. Cell 40: 271-281.

Yancopoulos, G.D., Desiderio, S.V., Paskind, M., Kearney, J.F., Baltimore, D., and Alt, F.W. 1984. Preferential utilization of the most $I_{H}$-proximal $V_{H}$ gene segments in pre-B-cell lines. Nature 311: 727-733. 


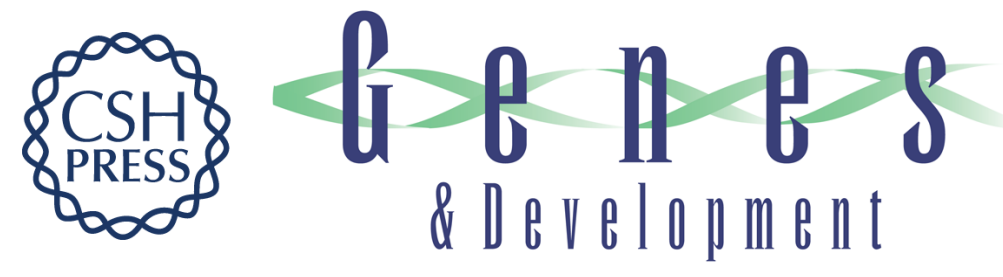

\section{Pax5 induces $V$-to- $D J$ rearrangements and locus contraction of the immunoglobulin heavy-chain gene}

Martin Fuxa, Jane Skok, Abdallah Souabni, et al.

Genes Dev. 2004, 18:

Access the most recent version at doi:10.1101/gad.291504

Supplemental
Material http://genesdev.cshlp.org/content/suppl/2004/02/13/18.4.411.DC1

References This article cites 58 articles, 23 of which can be accessed free at: http://genesdev.cshlp.org/content/18/4/411.full.html\#ref-list-1

License

Email Alerting Receive free email alerts when new articles cite this article - sign up in the box at the top Service right corner of the article or click here.

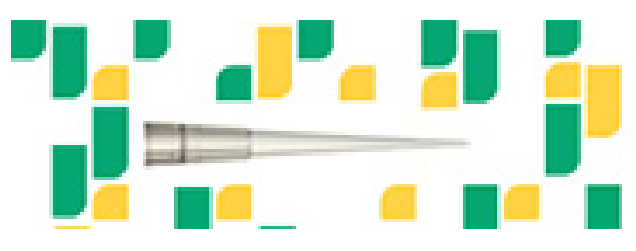

Focused on your science. 